\title{
Ex-vivo Surgical Repair of a Renal Artery Aneurysm with Kidney Autotransplantation
}

\author{
Cirurgia Ex-vivo para Tratamento de Aneurisma \\ da Artéria Renal com Autotransplante Renal
}

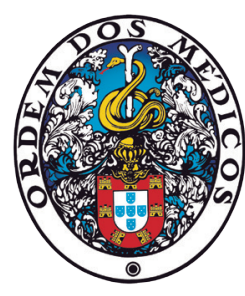

\author{
Gonçalo SOBRINHO ${ }^{1,2}$, Augusto MINISTRO ${ }^{1,2}$, Artur SILVA ${ }^{3,4}$, Luís PEDRO PI,2 $^{1,2}$ \\ Acta Med Port 2020 Oct;33(10):688-691 - https://doi.org/10.20344/amp.11127
}

\section{ABSTRACT}

Renal artery aneurysms are rare. They are most commonly degenerative, congenital or due to medial fibroplasia. Proximal aneurysms can be repaired by endovascular and in-situ surgical techniques. However, aneurysms of the distal renal artery and its branches require ex-vivo surgical repair, also known as auto-transplantation: the kidney is removed, dissected and reconstructed in cold ischemia, and put back in place. A 69-year-old woman, with hypertension, presented with bilateral renal artery aneurysms with a diameter of $3.4 \mathrm{~cm}$ on the right kidney and $1 \mathrm{~cm}$ on the left kidney. The right renal artery aneurysm, which was due to medial fibroplasia, was successfully repaired using the ex-vivo surgical technique. Patency was confirmed by postoperative computed tomography angiography.

Keywords: Aneurysm/surgery; Kidney Transplantation; Renal Artery/surgery; Transplantation, Autologous

\section{RESUMO}

Os aneurismas das artérias renais são raros. As etiologias mais comuns são a degenerativa, a fibroplasia da média e os defeitos congénitos. O tratamento endovascular e a cirurgia in-situ são adequados para os aneurismas proximais. O envolvimento da artéria renal distal e seus ramos requer tratamento cirúrgico ex-vivo que consiste num autotransplante: o rim é removido, dissecado e reconstruído em isquemia fria, e finalmente reimplantado. Uma mulher de 69 anos, apresentava hipertensão arterial e aneurismas bilaterais das artérias renais com $3.4 \mathrm{~cm}$ de diâmetro à direita e $1 \mathrm{~cm}$ à esquerda. $O$ aneurisma da artéria renal direita, de etiologia fibrodisplásica, foi tratado por cirurgia ex-vivo com sucesso. A angiotomografia computadorizada pós-operatória revelou a permeabilidade da reconstrução renal.

Palavras-chave: Aneurisma/cirurgia; Artéria Renal/cirurgia; Transplante Autólogo; Transplante de Rim

\section{INTRODUCTION}

Renal artery aneurysms are rare. They are most commonly degenerative, congenital or due to medial fibroplasia. ${ }^{1}$ Proximal aneurysms can be repaired by endovascular and in-situ surgical techniques. However, aneurysms of the distal renal artery and its branches require ex-vivo surgical repair, also known as auto-transplantation: the kidney is removed, dissected and reconstructed in cold ischemia, and put back in place. ${ }^{2}$

\section{CLINICAL CASE}

A 69-year-old Caucasian female presented with controlled hypertension (on four anti-hypertensive drugs), dyslipidemia, acute myocardial infarction (with a normal coronary angiography one year before), obesity, obstructive sleep apnea syndrome treated with continuous positive airway pressure (CPAP). She had a 40 pack-year smoking history until the age of 44 . In the workup for bilateral low back pain, a computed tomography angiography (CTA) revealed bilateral renal artery aneurysms (Fig. 1). Glomerular filtration measured by renal scintigraphy with $99 \mathrm{mTC}$-DTPA was $54 \mathrm{~mL} / \mathrm{min}$ (right), $46 \mathrm{~mL} / \mathrm{min}$ (left) and there was right excretory delay without significant mechanical obstruction. Serum creatinine was $0.90 \mathrm{mg} / \mathrm{dL}$ and hemoglobin was $10.3 \mathrm{~g} / \mathrm{dL}$. The ultrasound scan of the carotid and vertebral arteries showed no changes.

Ex-vivo surgical repair of the right renal aneurysm was carried out because the aneurysm involved the branches of the renal artery. This technique has been described in detail. ${ }^{2-5} \mathrm{~A}$ right retroperitoneal flank lazy-S shaped incision, extending from the tip of the $11^{\text {th }}$ rib to an area just medial to the McBurney point was used. The kidney was removed without dividing the ureter, encompassing a small ellipse of vena cava patch with the renal vein (which was closed longitudinally) to allow for a patch anastomosis, placed on the patient's abdomen, immersed in ice slush and perfused with Celsior ${ }^{\otimes}$ solution at $4^{\circ} \mathrm{C}$. The hilum was dissected and three branches distal to the aneurysm were identified. The two cephalic branches were syndactylized and the combined

\footnotetext{
1. Serviço de Cirurgia Vascular. Hospital Santa Maria. Centro Hospitalar Universitário Lisboa Norte. Lisboa. Portugal.

2. Departamento de Cirurgia Vascular. Faculdade de Medicina. Universidade de Lisboa. Centro Académico de Medicina de Lisboa. Lisboa. Portugal.

3. Serviço de Anatomia Patológica. Hospital Santa Maria. Centro Hospitalar Universitário Lisboa Norte. Lisboa. Portugal.

4. Serviço de Anatomia Patológica. Faculdade de Medicina. Universidade de Lisboa. Centro Académico de Medicina de Lisboa. Lisboa. Portugal.

$\square$ Autor correspondente: Gonçalo Sobrinho. gsobrinho@aim.com

Recebido: 19 de agosto de 2018 - Aceite: 26 de abril de 2019 | Copyright @ Ordem dos Médicos 2020
} 

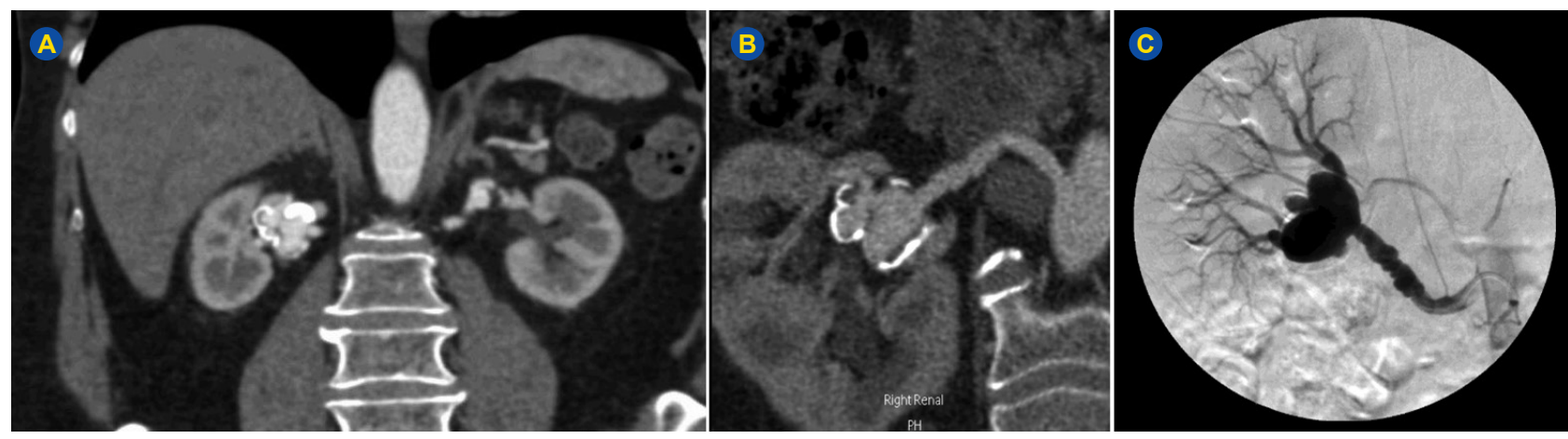

Figure $1-(\mathrm{A}, \mathrm{B})$ Abdominal computed tomography (CTA). Right renal artery hilar aneurysm $3.4 \times 2 \mathrm{~cm}$ in diameter and calcified. Distal left renal artery aneurysm $1 \mathrm{~cm}$ in diameter. The size of the kidneys, parenchymal thickness and contrast opacification were normal. There was also slight right pelvicalyceal dilation and a normal ureter. (C) Right renal artery angiography. Renal artery aneurysm at the hilum and 'string-of-beads' morphology in the remaining artery.

tube anastomosed to an autologous right hypogastric artery graft. The caudal branch was sewn end-to-side to this conduit (Fig. 2). The kidney was placed in its anatomical position (orthotopic). The reconstructed renal artery with hypogastric artery graft was routed posterior to the inferior vena cava and anastomosed to the distal abdominal aorta. The renal vein was anastomosed to the distal inferior vena cava.

The serum creatinine was $0.9 \mathrm{mg} / \mathrm{dL}$ in the preoperative period, $1.3 \mathrm{mg} / \mathrm{dL}$ on the third postoperative day and $0.8 \mathrm{mg} / \mathrm{dL}$ at discharge on the sixth postoperative day. The histopathological examination of the surgical specimen

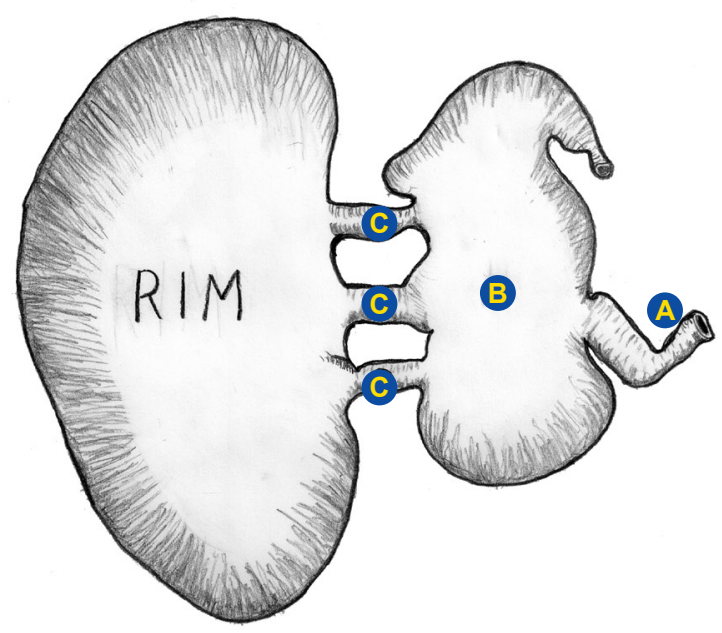

(D)

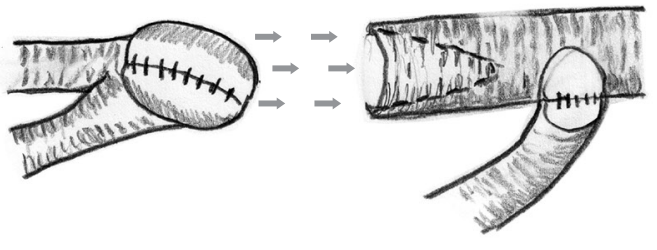

revealed medial fibromuscular dysplasia and a calcified macroaneurysm (Fig. 3). Postoperative CTA showed adequate right kidney reconstruction (Fig. 4). At 1-year followup, creatinine remains at $0.9 \mathrm{mg} / \mathrm{dL}$ on the same four antihypertensive drugs.

\section{DISCUSSION}

This case report shares many of the well-known epidemiological features of renal aneurysm due to medial fibromuscular dysplasia: higher incidence in females (4:1), Caucasians and smokers, more common involvement of the right renal artery $(3: 1)$, bilateral involvement $(25 \%$ of
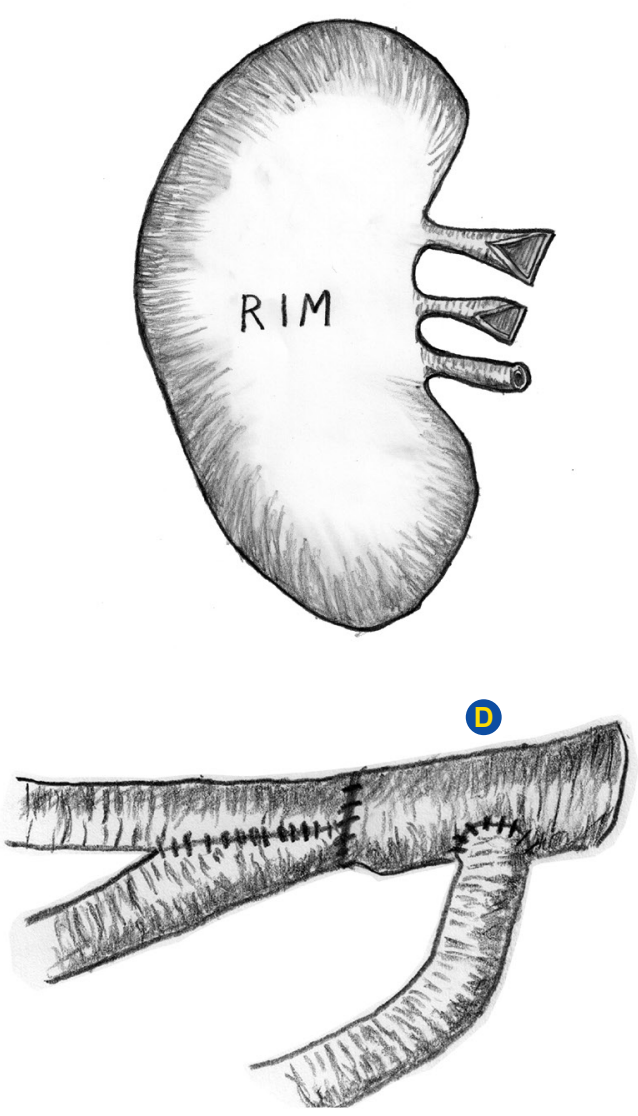

Figure 2 - Surgical reconstruction of the renal artery. (A) Proximal renal artery; (B) Aneurysm; (C) Hilar branches; (D) Hypogastric artery graft 

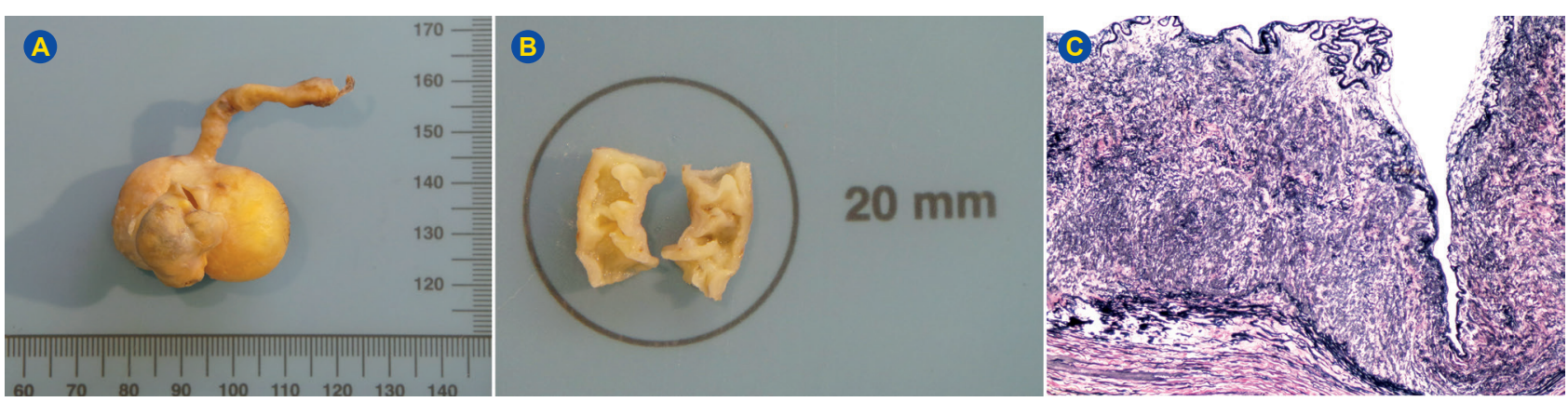

Figure 3 - Histopathological examination. (A) Renal artery macroaneurysm; (B) Longitudinal view of the renal artery with areas of stenosis and microaneurysms; (C) Histopathological examination of the renal artery with thickening and disorganization of the elastic and muscular tissue of the tunica media and microaneurysm (Verhoeff, $\mathrm{x} 400$ ).

cases), and coexistence of macroaneurysms of the renal artery ( $9.2 \%$ of cases). The age of diagnosis was 69 , later than usual $(20-60$ years), although the disease presumably existed before, as shown by the size and calcification of the aneurysm and the previous existence of hypertension, which is present in $81 \%$ of cases of renal artery aneurysm. ${ }^{6}$ Renal artery aneurysms are usually asymptomatic and therefore an incidental finding during the investigation for low back pain. However, the CTA and renal scintigraphy showed a slight right pelvicalyceal dilation that subsided after surgery and was most likely caused by aneurysm compression. The involvement of the carotid, coronary and vertebral arteries, which occurs in $20 \%-30 \%$ of the cases of arterial fibroplasia, was excluded by vertebral and carotid ultrasonography and coronary angiography. ${ }^{6}$ Renal artery aneurysms rupture occurs in probably less than $3 \%$ of cases and is associated with a mortality rate of $10 \%$ in men and in non-pregnant women. ${ }^{1}$ Pregnancy is associated with increased risk of rupture, maternal mortality rate of $55 \%$ and fetal death rate of $85 \% .{ }^{1}$ Renal artery aneurysm repair is recommended where size exceeds $2-3 \mathrm{~cm}$ or of any size in pregnant women or women of childbearing age. ${ }^{1}$

Nephrectomy was not a good option in a 69-year-old patient with a contralateral renal artery aneurysm, despite good clearance of both kidneys determined by renal scintigraphy. The endovascular approach, with embolization or stent placement, would exclude two of the three branches of the renal artery and was not considered. ${ }^{1}$ The hilar involvement would preclude adequate surgical exposure with in-situ surgery and a complex vascular reconstruction was anticipated to exceed 40 minutes of renal ischemia. An ex-vivo renal artery surgery was performed because it

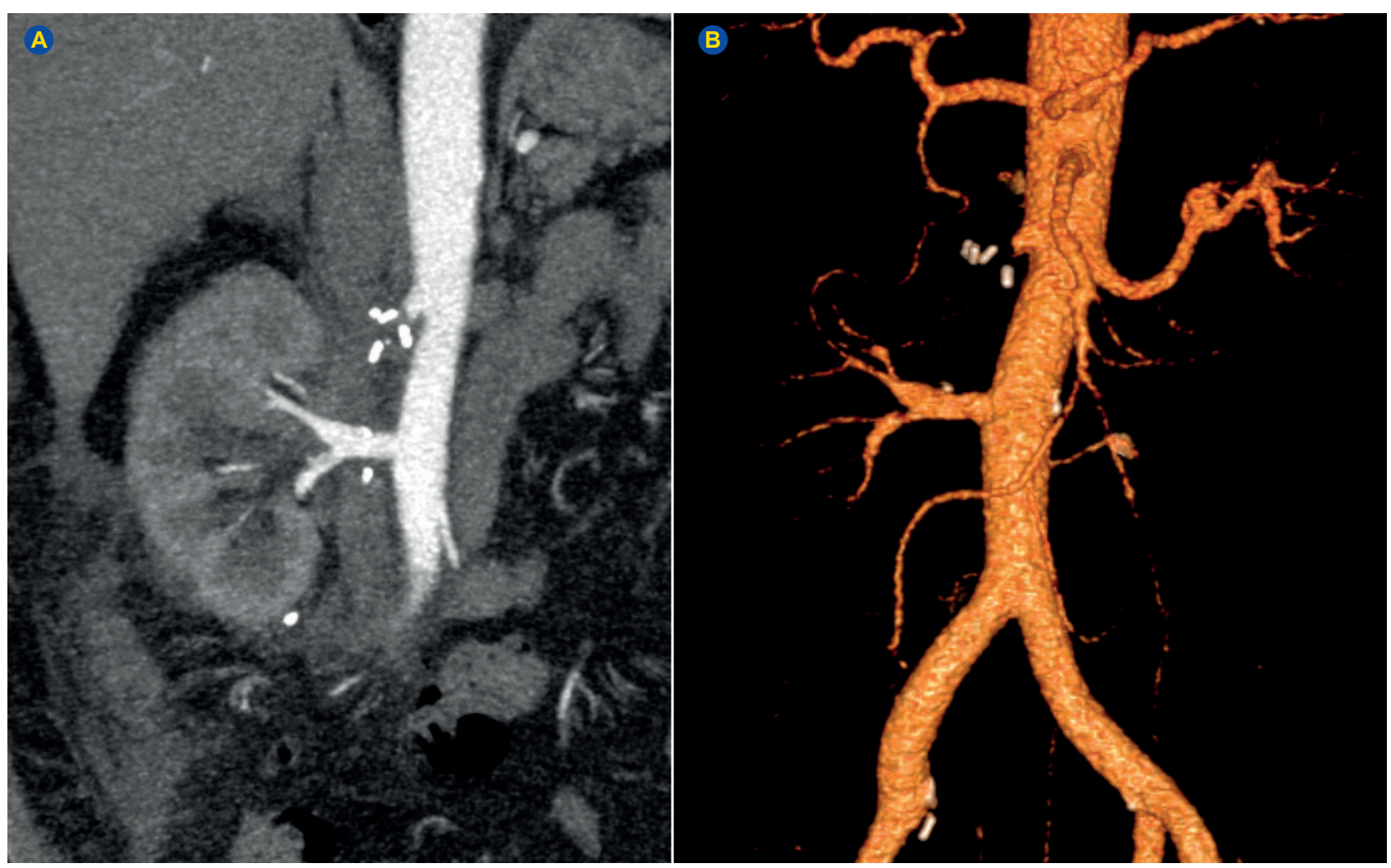

Figure 4 - Postoperative abdominal CTA (A, B). Right kidney with more caudal location, patency of the right renal artery reconstruction and absence of the hypogastric artery which was harvested and used as a graft. The minor preoperative right pelvicalyceal dilation subsided. 
obviates the constraints of in-situ renal artery surgery: surgical access for dissection and reconstruction becomes possible and cold perfusion allows for lengthy reconstructive times. The orthotopic auto-transplantation has advantages over the less invasive laparoscopic nephrectomy with autotransplantation of the repaired kidney in the iliac fossa: 1) the arterial reattachment is in the aorta which is less prone to atherosclerosis 2) the venous reattachment in the inferior vena cava obviates the need for right renal vein elongation 3 ) the ureter is not divided and does not require reimplantation 4) a single surgical retroperitoneal approach, even though it is more extensive, allows for both nephrectomy and auto-transplantation. The advantages of the hypogastric artery graft are durability without aneurysmal degeneration and the possibility of individual anastomoses to the branches of the renal artery, although this was not required on this occasion.

Crutchley reported a series with 77 patients, 78 surgeries for branches of the renal arteries, of which 50 were aneurysm, 49 by ex-vivo and 29 by in-situ surgery. There was no mortality and the primary patency at 1 year was $85 \%$. Among patients with hypertension $15 \%$ were cured, $65 \%$ were improved and $20 \%$ failed. Early renal function was improved in $35 \%$, unchanged in $48 \%$ and worse in $17 \% .^{2}$

Duprey reported a series with 67 patients, treated for 87 renal artery branch aneurysms by ex-vivo surgery. There was no mortality, the primary patency at 8 years was $88 \%$. There was benefit in the control of hypertension (43\% cure, $18 \%$ improvement) and preservation of the renal function. ${ }^{7}$

Ex-vivo renal artery surgery is the treatment of choice for distal renal artery lesions and its branches, which are not amenable to endovascular approach or in-situ surgery. It eliminates the risk of aneurysm rupture, improves the control of hypertension and preserves renal function that is important in young patients with bilateral and progressive disease in which one kidney may prove insufficient, or in patients with a single kidney.

\section{ACKNOWLEDGMENTS}

The authors would like to thank Paula Wright for the constructive remarks and improving the use of English in the manuscript.

\section{PROTECTION OF HUMANS AND ANIMALS}

The authors declare that the procedures were followed according to the regulations established by the Clinical Research and Ethics Committee and to the Helsinki Declaration of the World Medical Association.

\section{DATA CONFIDENTIALITY}

The authors declare having followed the protocols in use at their working center regarding patients' data publication.

\section{INFORMED CONSENT}

Obtained.

\section{CONFLICTS OF INTEREST}

All authors report no conflict of interest.

\section{FUNDING SOURCES}

The authors declare that there were no external sources of study for the performance of this article.

\section{REFERENCES}

1. Calligaro K, Dougherty M. Renovascular disease: aneurysms and arteriovenous fistulae. In: Rutherford RB, editor. Vascular surgery. $9^{\text {th }}$ ed. Philadelphia: WB Saunders; 2019. p. 1696-703.

2. Crutchley TA, Pearce JD, Craven TE, Edwards MS, Dean RH, Hansen $\mathrm{KJ}$. Branch renal artery repair with cold perfusion protection. J Vasc Surg. 2007;46:405-12.

3. Barral X, Lorin S, Grandmougin D, Favre JP. Chirurgie de l'artère rénale (II). Lésions congénitales de l'enfant dysplasies de l'adulte jeune. Encycl Méd Chir, Editions Scientifiques et Médicales Elsevier SAS, Paris, Techniques chirurgicales - Chirurgie vasculaire, 43-110-B, Techniques chirurgicales - Urologie, 41-105-B. 2002, p. 1-15.

4. Do Carmo G, Rosa A, Ministro A, Pestana C. "Ex-vivo" surgical repair

of renal artery branches aneurysms. Rev Port Cir Cardiotorac Vasc. 2012;19:95-8.

5. Nelms JK, Benjamin ME. Ex vivo renal repair: technical tips, when, and why. Semin Vasc Surg. 2013;26:199-204.

6. Avgerinos E, Schneider P, Chaer R. Fibromuscular dysplasia. In: Rutherford RB, editor. Vascular surgery. $9^{\text {th }}$ ed. Philadelphia: WB Saunders; 2019, p. 1870-90.

7. Duprey A, Chavent B, Meyer-Bisch V, Varin T, Albertini JN, Favre JP, et al. Ex vivo renal artery repair with kidney autotransplantation for renal artery branch aneurysms: long-term results of sixty-seven procedures. Eur J Vasc Endovasc Surg. 2016;51:872-9. 